\title{
Investigation to Increases the Strength and Workability of Concrete by Using Bottle Caps with Admixture
}

\author{
K. G. Devaki ${ }^{1,}$ J. Seenuvasan ${ }^{2}$. \\ ${ }^{1}$ Assistant professor, Erode Sengunthar Engineering College,devakinavin@gmail.com \\ ${ }^{2} U G$ Student, Erode Sengunthar Engineering College,seenuvasan.j18@ gmail.com
}

\begin{abstract}
Advancements in technology enhances not only human comforts but also damages the environment. Use of metals as containers has become popular and safe, especially to carry the liquids. Today the construction industry is in need of finding cost effective materials for increasing the strength of concrete structures. Hence an attempt has been made in the present investigations to study the influence of addition of waste materials like soft drink bottle caps from workshop at a dosage of 1.5\%, 2.5\%, 3.5\% of total weight of concrete as fibres. The soft drink bottle caps were deformed into the rectangular strips of $3 \mathrm{~mm}$ width and $10 \mathrm{~mm}$ length. Experimental investigation was done using M35 mix and tests were carried out as per recommended procedures by relevant codes. super plasticizers is practiced for production of flowing, self compacting and for the production of high strength and high performance concrete. In this investigation tecmix550 used as chemical admixture

Although the concrete is the most popular construction material, it has some limited properties, low tensile strength, low ductility, low energy absorption, and shrinkage, cracking associated with hardening and curing. The concrete was subjected to compressive strength, split tensile strength and flexural strength tested after 7 days, 14days and 28days
\end{abstract}

Keywords: bottle caps, M35 mix, tecmix550 chemical admixture

\section{Introduction}

Concrete has an extensive role to play in the construction and improvement of our civil engineering and infrastructure development. Its great strength, durability and veracity are the properties that are utilized in construction of Roads, Bridges, Airports, Railways, and Tunnels, Port, Harbours, and many other infrastructural project. Use of admixtures to concrete has long been practised since 1900. In the early 1900s, asbestos fibres were used in concrete. There was a need to find replacement for the asbestos used in concrete. By the 1960s, steel, glass (GFRC) and synthetic fibres such as polypropylene fibres were used in concrete.

Concrete in general weak in tensile strength and strong in compressive strength. The main object of this investigation is to improve the tensile strength of concrete. To overcome this serious defect partial incorporation of fibres is practised. Great quantities of steel waste fibers are generated from industries related to lathes, empty beverage metal cans and soft drink bottle caps. This is an environmental issue as steel waste fibres are difficult to biodegrade and involves processes either to recycle or reuse.The resulting compressive strength, split tensile strength and flexural strength of the mixture depends on the type of cement, size and type of aggregate, period and type of curing adopted.

Admixtures is defined as a material, other than cement, water and aggregate, that is used as an ingredient of concrete and is added to the batch immediately before or during mixing.Chemical admixture and Mineral admixture.

In this investigation tecmix 550 used as chemical admixture.The benefits and features of tecmix 550 are enhanced water reduction properties resulting in improved workability and greatly reduced porosity of concrete.Significantly reduces segregation and bleeding of concrete mix.Helps produce concrete of high early strength and also increase the ultimate compressive strength.An extremely useful admixture for pre-cast concrete. Improves final texture of concrete.Does not contain chloride. It is safe for use pre-stressed concrete.

The uses of tecmix 550areIdeal as an admixture for high volume concreting for floors, walls or foundations.Ideal for production of high strength concrete with reduced permeability by reducing the water content.Improved workability makes Tec mix550 suited for concreting in areas with congested reinforcement.Ideal for sloped roof concreting in areas and roof with complicated geometry like domes, shells and folded plate.

In this investigation mineral admixture are the metallic waste obtained from varies sources such as mild steel lathe waste, empty beverage tins, soft drink bottle caps are deformed into the rectangular from with an approximate size of $3 \mathrm{~mm}$ wide and $10 \mathrm{~mm}$ long as in the form of fibers. These fibers are added in the concrete with $1.5 \%, 2.5 \%$, and $3.5 \%$ by weight of concrete. Ordinary Portland Cement (OPC) 43 grade, and fine aggregate with less amount of clay and silt with sand size is pass through $1.19 \mathrm{~mm}$ sieve and retained on $900 \mathrm{micron}$ sieve. The coarse aggregate used in $20 \mathrm{~mm} \& 12.5 \mathrm{~mm}$ size. It is well graded and Potable water, free from impurities such as 
oil, alkalies, acids, salts, sugar, and organic materials were used. The quality of water was found to satisfy the requirement of IS $456-2000$. The concrete using grade M35 (1:1.43:2.825) with water cement ratio 0.45 were used

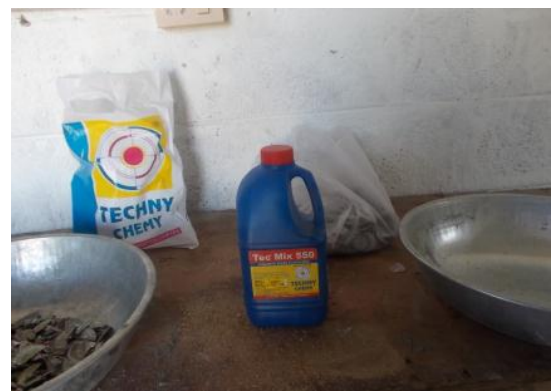

Figure .1 Tecmix550 Sample

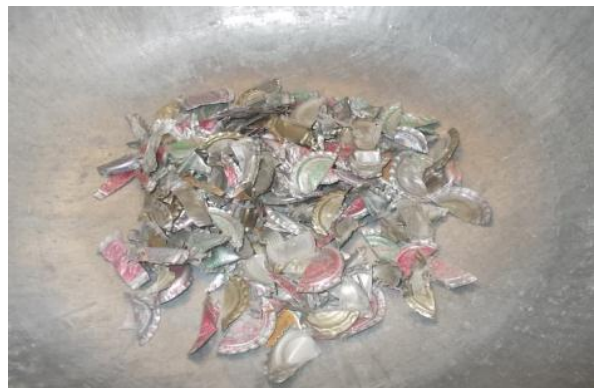

Figure 2 Sample Of Fiber

Table.1Technical Data For Tecmix550

\begin{tabular}{|l|l|}
\hline Physical data & Dark brown medium viscous liquid \\
\hline Base & Sulphonated naphthalene polymers \\
\hline Specific gravity & $1.20 \pm 0.02 @ 30^{0} \mathrm{c}$ \\
\hline PH Value & $7-9$ \\
\hline Air entrainment & $<1 \%$ compared to control concrete mix \\
\hline Chloride content & Nil as per IS 456 \\
\hline Compatibility & Compatible with all types of cement with the exception of high alumina cement \\
\hline Dosage & $250-350 \mathrm{ml} / 50 \mathrm{~kg}$ bag of cement \\
\hline
\end{tabular}

\section{Compressive Strength Results}

It has been observed that the concrete produced from $0 \%, 1.5 \%, 2.5 \%, \& 3.5 \%$ added of coarse aggregate by bottle caps, shows maximum compressive strength.

Table 2 Average Compressive Strength

\begin{tabular}{|c|c|c|c|}
\hline $\begin{array}{c}\% \text { of bottle } \\
\text { caps Added }\end{array}$ & $\begin{array}{l}7 \text { days } \\
\text { compressive } \\
\text { strength N/mm }\end{array}$ & $\begin{array}{l}\text { 14 days } \\
\text { compressive } \\
\text { strength N/mm }\end{array}$ & $\begin{array}{l}28 \text { days } \\
\text { compressive } \\
\text { strength N/mm }\end{array}$ \\
\hline $0 \%$ & 23.77 & 27.32 & 36.22 \\
\hline $1.5 \%$ & 23.94 & 28.42 & 36.61 \\
\hline $2.5 \%$ & 23.97 & 27.54 & 36.78 \\
\hline $3.5 \%$ & 24.01 & 27.19 & 36.60 \\
\hline
\end{tabular}

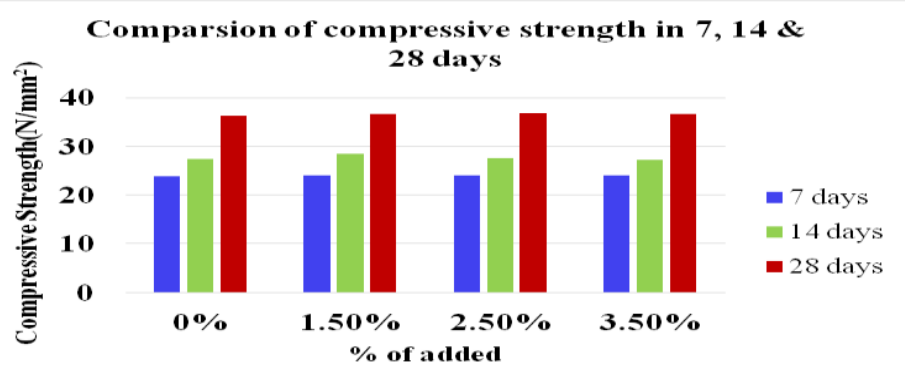

Figure 3: Comparsion of Compressive Strength Results for 7, 14, \& 28 days

\section{Split Tensile Test}

It has been observed that the concrete produced from $0 \%, 1.5 \%, 2.5 \%, \& 3.5 \%$ added of coarse aggregate by bottle caps, shows maximum tensile strength. 
Table 3 Average Tensile Strength

\begin{tabular}{|c|c|c|c|}
\hline $\begin{array}{l}\quad \% \text { of bottle } \\
\text { caps } \\
\text { Added }\end{array}$ & $\begin{array}{l}7 \text { days } \\
\text { compressive } \\
\text { strength } \mathrm{N} / \mathrm{mm}^{2}\end{array}$ & $\begin{array}{l}14 \text { days compressive } \\
\text { strength } \mathrm{N} / \mathrm{mm}^{2}\end{array}$ & $\begin{array}{l}28 \text { days compressive } \\
\text { strength } \mathrm{N} / \mathrm{mm}^{2}\end{array}$ \\
\hline $0 \%$ & 1.55 & 2.06 & 2.56 \\
\hline $1.5 \%$ & 1.57 & 2.11 & 2.57 \\
\hline $2.5 \%$ & 1.59 & 2.19 & 2.58 \\
\hline $3.5 \%$ & 1.62 & 2.31 & 2.64 \\
\hline
\end{tabular}

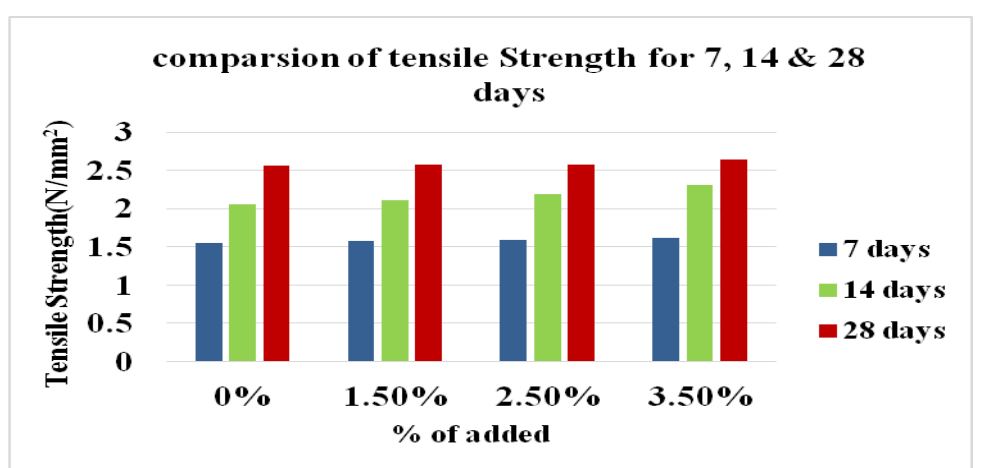

Flexural test:

Figure4: Comparsion Of Tensile Strength For Results 7, 14, \& 28 Days

It has been observed that the concrete produced from $0 \%, 1.5 \%, 2.5 \%, \& 3.5 \%$ added of coarse aggregate by bottle caps, shows maximum flexural strength.

Table 4 Average Flexural Strength

\begin{tabular}{|c|l|c|c|}
\hline $\begin{array}{l}\% \text { of bottle } \\
\text { caps }\end{array}$ & $\begin{array}{l}7 \text { days } \\
\text { compressive } \\
\text { strength N/mm }\end{array}$ & $\begin{array}{l}14 \text { days } \\
\text { compressive } \\
\text { strength N/mm }\end{array}$ & $\begin{array}{l}28 \text { days compressive } \\
\text { strength } \mathrm{N} / \mathrm{mm}^{2}\end{array}$ \\
\hline $0 \%$ & 5.12 & 5.52 & 6.00 \\
\hline $1.5 \%$ & 5.14 & 5.54 & 6.03 \\
\hline $2.5 \%$ & 5.17 & 5.59 & 6.07 \\
\hline $3.5 \%$ & 5.27 & 5.68 & 6.14 \\
\hline
\end{tabular}

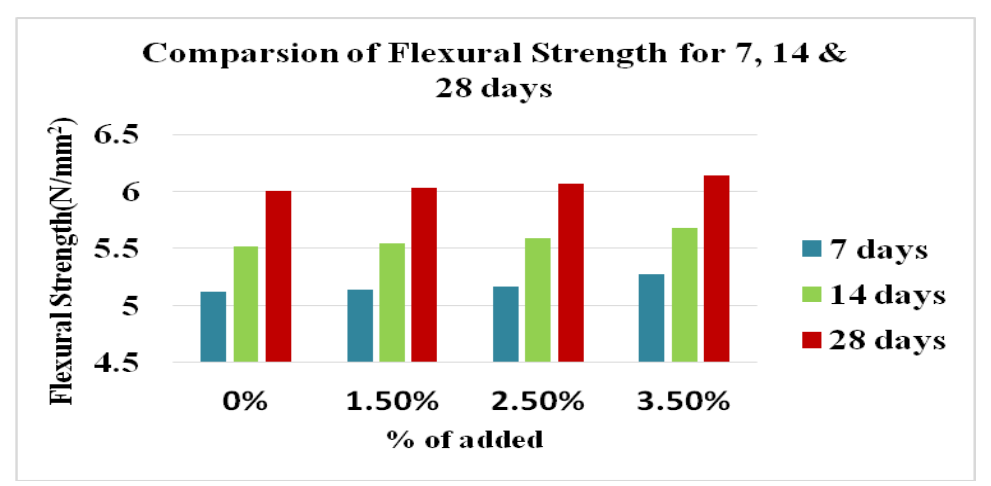

Figure 5: Comparsion Of Flexural Strength For Results 7, 14 \& 28 Days

\section{Result And Discussion}

The test results of compressive strength, split tensile strength and flexural strength shows the consistent increase upto $1.50 \%$ and $3.50 \%$ added respectively by bottle caps. Super plasticizer techmix 550 has used about $250 \mathrm{ml}$ per bag of cement which increase the strength of concrete.

\section{Conclusion :}

Based on this experimental investigation, the behavior of bottle caps in concrete is concluded below

$>$ The specimen with tecmix550 was found to be good in compression which had the compressive strength more than the conventional concrete.

$>$ Better split tensile strength was achieved with the addition of the bottle cap waste in concrete. The strength has increased when compared to that of the conventional concrete specimen. 
In flexure the specimen with soft drink bottle caps as waste material was found to be good. While adding the soft drink bottle caps the flexural strength increased than the conventional concrete.

Hence this concept of mixing is good for strength and workability of concrete.

\section{Suggestion For Future Work:}

$>$ There is scope for doing further investigation to increase the strength by analyzing durability properties.

$>$ Further this experiment can be extended to the field conditions, real time condition also.

\section{Reference:}

[1] IS: 383-1970, "specification for coarse and fine aggregate from natural sources for concrete", Bureau of Indian standards, New Delhi.

[2] Youjiang Wang H.C.Wu and Vitor C.Li (2000), “Concrete Reinforcement with Recycled Fibers”,Journal of Materials In Civil Engineering / November 2000.

[3] Shetty, M.S (2001) "Concrete technology theory and practice", S.Chand and company.

[4] Saud Al Otaibi(2008), "Recycling Steel Mill Scale as Fine Aggregate in Cement Mortars", European Journal of Scientific Research,Volume. 24, No.3, ISSN 1450-216X.

[5] Venu Malagavelli and Neelakanteswara Rao Patura,(2011), "Strength Characteristics of Concrete Using Solid Waste an Experimental Investigation", International Journalof Earth Sciences and Engineering, Volume. 4, No. 6, ISSN 0974-5904.

[6] Zainab Z.Ismail and Enas a.Al-Hashmi (2011), "Validation of Using Mixed Iron and Plastic Wastes in Concrete", Second International Conference on Sustainable Construction Materials and technologies, ISBN 978-1-4507-1490-7. 